\title{
Global Activity, Impact and Collaborative Trends of Business Research - A Bibliometric Research
}

\author{
Ranjita Mishra, D.B. Ramesh
}

\begin{abstract}
An analysis of global publication productivity, impact and trend of collaborations in business research using Scopus database during the period 1998-2017 is presented. Bibliometric techniques are used for analysis of data. This study finds, 2016 and 2017 as productive and collaborative, whereas 2005, 2007 and 2006 as highly cited years. Collaborative papers are above 50\% and Kasemsap, $K$. is the most productive author and all his papers are single authored. Hong Kong Polytechnic University of China has greater productivity, Collaborative papers and second highest citations gained. United States and United Kingdom leads for their productivity and citations received but their collaborative efforts are less than 50\%. India has 7 th position with 1538 (3.11\%) publication share. Journal of Business Ethics is the highest productive journal. Harvard Business Review is the highly cited journal. Porter, M. E. is the highly cited author having 3389 citations for his single contribution. Out of top 10 highly cited papers six are single authored.
\end{abstract}

Keywords: Business productivity; collaborations; research impact; International Collaborations

\section{INTRODUCTION}

Business is an economic activity which is concerned with exchange of goods and services. The prior concept of business $^{1}$ was based on gaining maximum profits as the slogan says "the business of business is to do business". Later it was changed to "profit with service". But the modern concepts of business rely on "profits through service". There may be business for the benefits of society at no profit and no loss basis.

Many business industries like manufacturing, agriculture, information and communication technology, healthcare etc prefer high expenses on research and development (R\&D) for better and innovative services. $R \& D^{2}$ helps to succeed among competitors and can increase the revenue. $R \& D$ fulfills need of the society and supports country's financial condition. Hence evaluation of global business publications is important and reviews of previous literature indicate a research gap in this area. Bibliometrics is a research methods used to evaluate quantitative and qualitative performance of research. The study aims to analyse global performance of business research through three angles that is, Publication productivity, Impact through citation and collaboration trends, collecting data from Scopus database

Revised Manuscript Received on 14 August, 2019.

Ranjita Mishra, Asst Librarian, Siksha 'O' Anusandhan Deemed to be University, Bhubaneswar, Odisha, India.(Email: ranjitamishraibcs@gmail.com)

Dr. D.B. Ramesh, Chief Librarian, Siksha 'O' Anusandhan Deemed to be University, Bhubaneswar, Odisha, India.(Email: dolababuramesh@soa.ac.in) acquisition of money and wealth through production and

during 1998-2017. Analysis of productivity reflects research activity/ publication behavior and analysis of citation reflects research quality. As future success of business depends on collaboration and it increases visibility of research, analysis of collaborative efforts is intended.

\section{REVIEW OF LITERATURE}

Bhardwaj ${ }^{3}$ discussed the global publication trend of international business analysing 3131 journals and 1623 papers of Social Sciences Citation Index from 2004-2013. The study reveals that an average publication per year is 162.30. Highest 268 papers published in 2010. The study will assist the researchers, publishers and librarians in selecting prominent and demanded journals. Talukdar ${ }^{4}$ observed the productivity patterns of the business ethics research. Two leading business ethics journals are examined and Lotka's law is tested. Publication productivity in business ethics is consistently growing like other business areas. Dahlgaard-Park and Anninos ${ }^{5}$ aims to examine ancient Hellenic philosophy, various schools of management thought and application of these in universities. Ancient Hellenes philosopher's 2,400 years ago writings indicate their considerable contribution towards the development of excellence and TQM concept. Iritani et al ${ }^{6}$ analysed theory and practice of (BPM) Business Process Management. The study confirms the multidisciplinary nature of BPM and it is practiced by different research areas. The study marked eight types of BPM practices. Sengar, Naqvi and Eqbal ${ }^{7}$ examines 213 articles of the management journal Pranjana for 2001 to 2010. The study reveals single authored papers are more than multi authored papers. Among the countries US contributes maximum. Calabretta, Durisin and Ogliengo ${ }^{8}$ examine Journal of Business Ethics to know its growth, trends and present status. The authors adopted citation and co citation analysis and able to recognize growth, significant papers and various business ethics schools. Jabeen et al ${ }^{9}$ tried to explore library scholar's productivity. Forty LIS journals from Journal Citation Report 2010 were collected and analysed using bibliometric techniques. Total 18371 articles published during 20032012. Highest growth rate of $11.37 \%$ was found in 2009 . Trend of self citation has been increased in $36.56 \%$. China has remarkable contribution in collaborative research. Fiala and Willett ${ }^{10}$ discussed degree of collaboration in computer science in Eastern Europe during 1989 to2014. The study found that there are $7.2 \%$ collaborative papers of Slovak

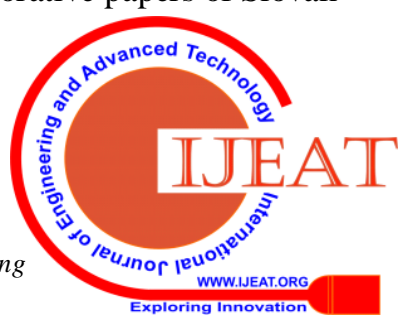




\section{GLOBAL ACTIVITY, IMPACT AND COLLABORATIVE TRENDS OF BUSINESS RESEARCH - A BIBLIOMETRIC RESEARCH}

with Czech authors, but $2.0 \%$ collaborative papers of Czech with Slovak authors.

\section{OBJECTIVE}

The objective of the study is to find out global Productivity, it's Impact and Collaborative trends of Business Research. The study proceeds on to uncover the followings:

- $\quad$ Annual Trend

- $\quad$ Productive Researcher's Trend

- $\quad$ Trend of Productive Institutions and countries

- $\quad$ Productive Journals and their Citation Impact

- $\quad$ Highly Cited Authors and Papers

\section{METHODOLOGY}

Data source selected for the study is Scopus database. Data collected for the sample period is 1998 to 2017 on $7^{\text {th }}$ March 2018. Data collection process consist of, within document search of Scopus, "business management" for Article Title, Abstract, Keywords is searched. Then Subject area "Business, Management and Accounting" and then year 1998 to 2017 is limited. Total 49417 data resulted. Whenever required, data is further refined as per different available parameters like Author name, Source title, Affiliation, Country/territory, Source type etc. and exported/downloaded as CSV Excel file. The method of study is bibliometrics.

\section{RESULTS AND DISCUSSION}

\section{Annual Trend}

Bibliometrics is vital for funding decisions regarding research and development. Bibliometric techniques are not only used to measure quantitative aspect of research through publication count but also uncover the quality/ impact of research areas, researchers and research articles. Analysis of citation is a means to evaluate quality of research performance. It is based on citation count of researchers, institutes etc. There is a theme or subject relation between the citing and cited document. It reflects influential contributions and contributors. As collaboration increases visibility and sharing of research is a part of communication process. There may be collaborations among authors, subjects, institutions and nations. Since last twenty years collaborative trend has been increased and turned into a requirement of modern scientific communication.

Table 1. Annual trend of Productivity, Impact and Collaboration

\begin{tabular}{lllllll}
\hline Year & Papers (P) & \%age & Cit & Impact (C/P) & Coll Papers & \%age \\
\hline 1998 & 721 & 1.46 & 32433 & 44.98 & 377 & 52.29 \\
1999 & 792 & 1.60 & 32072 & 40.49 & 450 & 56.82 \\
2000 & 881 & 1.78 & 36020 & 40.89 & 460 & 52.21 \\
2001 & 936 & 1.89 & 46385 & 49.56 & 489 & 52.24 \\
2002 & 1128 & 2.28 & 39690 & 35.19 & 637 & 56.47 \\
2003 & 1519 & 3.07 & 46878 & 30.86 & 826 & 54.38 \\
2004 & 1609 & 3.26 & 49712 & 30.90 & 836 & 51.96 \\
2005 & 2141 & 4.33 & 60566 & 28.29 & 1166 & 54.46 \\
2006 & 2312 & 4.68 & 56496 & 24.44 & 1405 & 60.77 \\
2007 & 2501 & 5.06 & 59156 & 23.65 & 1569 & 62.73 \\
2008 & 2794 & 5.65 & 54614 & 19.55 & 1869 & 66.89 \\
2009 & 3190 & 6.46 & 47347 & 14.84 & 2118 & 66.39 \\
2010 & 3465 & 7.01 & 51615 & 14.90 & 2375 & 68.54 \\
2011 & 3651 & 7.39 & 38619 & 10.58 & 2538 & 69.52 \\
2012 & 3196 & 6.47 & 34709 & 10.86 & 2260 & 70.71 \\
2013 & 3593 & 7.27 & 29539 & 8.22 & 2606 & 72.53 \\
2014 & 3272 & 6.62 & 21060 & 6.44 & 2421 & 73.99 \\
2015 & 3622 & 7.33 & 17175 & 4.74 & 2716 & 74.99 \\
2016 & 4349 & 8.80 & 9612 & 2.21 & 3371 & 77.51 \\
2017 & 3745 & 7.58 & 3348 & 0.89 & 2864 & 76.48 \\
Total & 49417 & 100 & 767046 & 15.52 & 33353 & 67.49 \\
\hline Correlation of productivity and citations & & & & 0.98 \\
Correlation of citations and collaborations & & & & 0.98 \\
\hline
\end{tabular}


Table 1 displays annual publication productivity, its impact through citation and collaborative efforts of business researchers during 1998-2017. Out of total 49417 papers highest contribution is found in 2016 is 4349 (8.80\%). Except the years 2012, 2014 and 2017 positive growths are recorded. For the year 2017 we can say that data may be added later in Scopus database Average growth per year is 2470.85. The citation pattern reveals that up to 2005 citation increases and highest 60566 citations are received in the year 2005 following 59156 in 2007 . Where as in 2001 highest citation per paper (49.56) are found following 1998 (44.98). Upward annual trend of collaborative efforts are found. Highest collaborative papers 3371 in 2016 and 2864 in 2017 are noticed. During the study period collaborative papers are above 50\%. It means since 1998 researchers in this field had shown their interest towards collaborative works. Total 49417 papers received 767046 citations and out of them $33353(67.49 \%)$ papers are collaborative.

The statistical technique Correlation (r) ${ }^{11}$ signifies the degrees of relationship between two distinct variables. It ranges between -1 to +1 . When $r=+1$, it means there is positive and strong relationship, when $r=-1$, it means there is strong and negative relationship. When $r=0$, it indicates there is no relationship between two variables. Here the inbuilt Karl Pearson correlation formula in Excel has been applied on the data of productivity and citations, and between citations and collaborations which resulted as 0.98 each. It is very close to +1 , which means there exist significant positive relationship between productivity and citations and also between citations and collaborations. It means both the values increase together.

\section{Productive Researcher's Trend}

Table 2 shows trend of productive business researchers. Kasemsap, K. of Thailand is the rank one author with 54 papers, following Smith, A. D. of United States with 52 and Mendling, J. of Austria with 43 papers. H- index $^{12}$ is introduced by J. E. Hirsch in 2005 is a metric which measure an author's publications as well as citations. An author has index $h$ if $h$ of his papers has been cited at least $h$ times. Here we find Gunasekaran, A. who is rank 4th author has highest h-index of 22 following Mendling J. , Kumar, S. and Svensson, G. with 12 h-index each. Kasemsap, K. and Annon who is rank 1 and 5th author have no collaborative papers. Kodama, M. who is ranked $6^{\text {th }}$ has only one multi author paper. On the other hand, Weske, M. and Helo, P. have no single authored papers means all their papers are multi authored.

Table 2. Top 10 productive Researchers and their trend

\begin{tabular}{|c|c|c|c|c|c|c|}
\hline Rank & Author Name & Affiliating Instituions & Paper & cit & $\begin{array}{l}\text { h- } \\
\text { index }\end{array}$ & $\begin{array}{l}\text { Coll } \\
\text { Work }\end{array}$ \\
\hline 1 & Kasemsap, K. & $\begin{array}{l}\text { SuanSunandha Rajabhat University, } \\
\text { Bangkok, Thailand }\end{array}$ & 54 & 372 & 11 & 0 \\
\hline 2 & Smith, A.D. & $\begin{array}{l}\text { Robert Morris University, Pittsburgh, } \\
\text { United States }\end{array}$ & 52 & 48 & 11 & 21 \\
\hline 3 & Mendling, J. & $\begin{array}{l}\text { Wirtschaftsuniversitat Wien, Vienna, } \\
\text { Austria }\end{array}$ & 43 & 942 & 12 & 42 \\
\hline 4 & $\begin{array}{l}\text { Gunasekaran, } \\
\text { A. }\end{array}$ & $\begin{array}{l}\text { California State University Bakersfield, } \\
\text { School of Business and Public } \\
\text { Administration, United States }\end{array}$ & 41 & 2578 & 22 & 39 \\
\hline 5 & Anon & Al-Quds University, Bethlehem, Palestine & 38 & 5 & 1 & 0 \\
\hline 6 & Kodama, M. & $\begin{array}{l}\text { Nihon University, College of Commerce, } \\
\text { Tokyo, Japan }\end{array}$ & 35 & 449 & 11 & 1 \\
\hline 7 & Kumar, S. & $\begin{array}{l}\text { University of St. Thomas, Minnesota, } \\
\text { United States }\end{array}$ & 34 & 706 & 12 & 33 \\
\hline 8 & Svensson, G. & $\begin{array}{l}\text { Oslo School of Management, Oslo, } \\
\text { Norway }\end{array}$ & 32 & 557 & 12 & 15 \\
\hline 8 & Weske, M. & $\begin{array}{l}\text { Hasso-Plattner-Institut fur } \\
\text { Softwaresystemtechnik GmbH, Germany }\end{array}$ & 32 & 241 & 6 & 32 \\
\hline 9 & Helo, P. & University of Vaasa, Finland & 31 & 353 & 7 & 31 \\
\hline
\end{tabular}

\section{Trend of Productive Institutions}

In table 3 top 10 productive institutions are displayed with their citations and collaborations. These top 10 institutions are from seven countries and contribute $5 \%$ of the total productivity, $7.65 \%$ of the total citations received and $4.30 \%$ of the total collaborated papers. Hong Kong Polytechnic University of China has highest productivity with 353 papers following Aalto University with 297 University of Manchester with 265 papers. Highest citations of 9630 are received by Cranfield University of UK, following Hong Kong Polytechnic University with 8117 and 
Erasmus University Rotterdam with 7836. Hong Kong papers following Copenhagen Business School and Erasmus Polytechnic University again has highest collaborating University Rotterdam.

Table 3. Top 10 Productive Institutions, their Impact and Collaborative efforts

\begin{tabular}{llllll}
\hline S N & Inst & Country & Papers & Cit & $\begin{array}{l}\text { Coll } \\
\text { Papers }\end{array}$ \\
\hline 1 & Hong Kong Polytechnic University & China & 353 & 8117 & 237 \\
2 & Aalto University & Finland & 297 & 7426 & 157 \\
3 & University of Manchester & U K & 265 & 6488 & 138 \\
4 & Cranfield University & U K & 258 & 9630 & 137 \\
5 & The University of Warwick & U K & 237 & 6657 & 110 \\
6 & Monash University & Australia & 235 & 4771 & 118 \\
7 & Erasmus University Rotterdam & Netherlands & 231 & 7836 & 173 \\
8 & Copenhagen Business School & Denmark & 200 & 4276 & 174 \\
9 & University of South Australia & Australia & 197 & 2120 & 86 \\
10 & Universidade de Sao Paulo - USP & Brazil & 196 & 1338 & 105
\end{tabular}

\section{Trend of Productive Countries}

Table 4 shows productive countries performance. They contribute $68.67 \%$ of the total productivity, $95.08 \%$ of the total citation received and $48.01 \%$ of the total collaborating papers. It means these countries are not only highly productive but also highly cited countries. United States is rank one productive country followed by United Kingdom, Australia and Germany. India has 7th position with 1538 (3.11\%) publication share. The top three productive countries are also top three cited country. Like United States is the highly cited country with 323294 citations and its citation per paper is 26.90. It is followed by United Kingdom and Australia. China has the lowest citation per paper. The Internationalisation Index of Netherlands is higher with 88.81. It is followed by Canada, Germany and Australia. The countries United States and United Kingdom are highly productive and highly cited countries in global scenario in business research but their collaborative trend is less than $50 \%$.

Table 4. Top 10 Productive Countries, their Impact and International Collaborations

\begin{tabular}{llllllll}
\hline $\mathrm{S}$ & Countries & Papers & \%age & Cit & $\begin{array}{l}\text { Impact } \\
\mathrm{C} / \mathrm{P}\end{array}$ & $\begin{array}{l}\text { Int. Coll } \\
\text { Papers }\end{array}$ & $\begin{array}{l}\text { Internation } \\
\text { alisation } \\
\text { Index }\end{array}$ \\
\hline 1 & & & & & & & \\
2 & United States & 12019 & 24.32 & 323294 & 26.90 & 4227 & 35.17 \\
3 & Anited Kingdom & 6404 & 12.96 & 151195 & 23.61 & 3048 & 47.60 \\
4 & Germany & 2952 & 5.97 & 54813 & 18.57 & 1675 & 56.74 \\
5 & China & 2541 & 5.14 & 19942 & 7.85 & 1172 & 46.12 \\
6 & Canada & 1740 & 3.52 & 46291 & 26.60 & 1273 & 73.16 \\
7 & India & 1538 & 3.11 & 17013 & 11.06 & 427 & 27.76 \\
8 & Spain & 1535 & 3.11 & 27259 & 17.76 & 829 & 54.01 \\
9 & Italy & 1350 & 2.73 & 18181 & 13.47 & 757 & 56.07 \\
10 & Netherlands & 1260 & 2.55 & 34435 & 27.33 & 1119 & 88.81 \\
& Total & 33933 & 68.67 & 729326 & & 16014 &
\end{tabular}




\section{GLOBAL ACTIVITY, IMPACT AND COLLABORATIVE TRENDS OF BUSINESS RESEARCH - A BIBLIOMETRIC RESEARCH}

\section{Trend of productive Journals}

Table 5 displays leading 10 productive journals which contribute $8.75 \%$ of the total productivity, published by five publishers from four countries. Journal of Business Ethics accounts for $2.22 \%$ contributions, following Strategic Direction with $1.30 \%$, Business Process Management Journal with $0.80 \%$. Out of these, journals published by Emerald have $1661(3.36 \%)$ and journals from UK have
1937 (3.92\%) papers. Impact Factors of three journals are not available. And among the rest journals, Journal of Cleaner Production of Elsevier has greater IF of 5.715, following Elsevier's International Journal of Production Economics with 3.493 and Harvard Business Review published by Harvard Business School Publishing with 3.227 .

Table 5. Productive Journals and their Citation Impact

\begin{tabular}{|c|c|c|c|c|c|c|}
\hline $\mathrm{S} \mathrm{N}$ & Journal Name & Publisher & $\begin{array}{l}\text { Country of } \\
\text { Origin }\end{array}$ & Papers & \%age & $\begin{array}{l}\text { IF } \\
(2016)\end{array}$ \\
\hline 1 & Journal Of Business Ethics & $\begin{array}{l}\text { Springer } \\
\text { Science+Business } \\
\text { Media }\end{array}$ & Germany & 1096 & 2.22 & 2.354 \\
\hline 2 & Strategic Direction & Emerald & UK & 642 & 1.30 & $* * *$ \\
\hline 3 & $\begin{array}{l}\text { Business Process } \\
\text { Management Journal }\end{array}$ & Emerald & UK & 396 & 0.80 & $\begin{array}{l}1.308 \\
(2017)\end{array}$ \\
\hline 4 & Harvard Business Review & $\begin{array}{l}\text { Harvard Bus } \\
\text { School Publishing }\end{array}$ & US & 381 & 0.77 & 3.227 \\
\hline 5 & $\begin{array}{l}\text { Journal Of Cleaner } \\
\text { Production }\end{array}$ & Elsevier & Netherlands & 330 & 0.67 & 5.715 \\
\hline 6 & Management Decision & Emerald & UK & 319 & 0.65 & 1.396 \\
\hline 7 & $\begin{array}{l}\text { Journal Of Management } \\
\text { Development }\end{array}$ & Emerald & UK & 304 & 0.62 & $* * *$ \\
\hline 8 & $\begin{array}{ll}\text { Industrial } & \text { Marketing } \\
\text { Management } & \end{array}$ & Elsevier & Netherlands & 297 & 0.60 & 3.166 \\
\hline 9 & $\begin{array}{l}\text { International Journal Of } \\
\text { Production Economics }\end{array}$ & Elsevier & Netherlands & 282 & 0.57 & 3.493 \\
\hline 10 & $\begin{array}{l}\text { Total Quality Management } \\
\text { And Business Excellence }\end{array}$ & Taylor \& Francis & UK & 276 & 0.56 & $* * *$ \\
\hline
\end{tabular}

\section{Highly Cited Authors}

Table 6 reflects highly cited authors and papers. This list includes all document types. Here we find except sl no 9 which one is a review, rest of top 10 are articles. Porter, M. E. is the highly cited author having 3389 citations for his single contribution entitled "Clusters and the new economics of competition". Likewise Hansen, M.T., Nohria, N. \& Tierney, T. are second highest cited authors having 2327 citations for their paper entitled "What's your strategy for managing knowledge?", following Orlitzky, M., Schmidt, F.L. \&Rynes, S.L. with 2266 citations for the paper entitles "Corporate social and financial performance: A metaanalysis". Among these top 10 cited papers four are published in Harvard Business Review, which is the highly cited journal and 9573 citations are received. On the other hand out of these 10 papers six papers are single authored papers.

Table 6. Highly Cited Authors and their Papers

\begin{tabular}{|c|c|c|c|}
\hline $\mathrm{SN}$ & Authors and Publication Details & Paper Title & Cit \\
\hline 1 & $\begin{array}{l}\text { Porter M.E. Harvard business review, 76(6), } \\
\text { 1998, 77-90p. }\end{array}$ & $\begin{array}{l}\text { Clusters and the new economics of } \\
\text { competition. }\end{array}$ & 3389 \\
\hline 2 & $\begin{array}{l}\text { Hansen M.T., Nohria N. \& Tierney T. } \\
\text { Harvard business review, 77(2), 1999, 106- } \\
\text { 116, 187p. }\end{array}$ & $\begin{array}{l}\text { What's your strategy for managing } \\
\text { knowledge? }\end{array}$ & 2327 \\
\hline 3 & $\begin{array}{l}\text { Orlitzky M., Schmidt F.L. \&Rynes S.L. } \\
\text { Organization Studies, 24(3), 2003, 403-441p. }\end{array}$ & $\begin{array}{l}\text { Corporate social and financial } \\
\text { performance: A meta-analysis }\end{array}$ & 2266 \\
\hline 4 & $\begin{array}{l}\text { Davenport T.H. Harvard business review, } \\
\text { 76(4), 1998, 121-131p. }\end{array}$ & $\begin{array}{l}\text { Putting the enterprise into the } \\
\text { enterprise system. }\end{array}$ & 1961 \\
\hline 5 & $\begin{array}{l}\text { Porter M.E. Harvard business review, 79(3), } \\
\text { 2001, 62-78, 164p. }\end{array}$ & Strategy and the Internet. & 1896 \\
\hline
\end{tabular}


Amit R. \&Zott C. Strategic Management Value creation in e-business Journal, 22(7 Jun), 2001, 493-520p.

7 Gold A.H., Malhotra A. \&Segars A.H. Journal of Management Information Systems, 18(1), 2001, 185-214p.

8

Teece D.J. Long Range Planning, 43(3 Feb), 2010, 172-194p.

9

Srivastava S.K. International Journal of Management Reviews, 9(1), 2007, 53-80p.

10 Sarasvathy S.D. Academy of Management Review, 26(2), 2001, 243-263p.
Knowledge management: An organizational capabilities perspective

Business models, business strategy and innovation

Green supply-chain management: A

1439 state-of-the-art literature review

Causation and effectuation: Toward 1408 a theoretical shift from economic inevitability to entrepreneurial contingency

\section{CONCLUSION}

The study reveals average growth per year is 2470.85 . Highest publications and collaborations are found in 2016 and 2017. Whereas highest citations received in 2005, 2007 and 2006. During the study period collaborative papers are above $50 \%$. There exist significant positive relationship between productivity and citations and also between citations and collaborations. Kasemsap, K. is the most productive author with 54 papers which are all single authored. Among these top ten authors Gunasekaran, A. is highly cited author. Hong Kong Polytechnic University of China has highest productivity, Collaborative papers and second highest citations gained. The countries United States and United Kingdom are highly productive and highly cited but their collaborative trend is less than $50 \%$. India has 7th position with $1538(3.11 \%)$ publication share. Journal of Business Ethics is leading journal with 1096 papers and 2.354 Impact Factor. Porter, M. E. is the highly cited author having 3389 citations for his single effort entitled "Clusters and the new economics of competition". Harvard Business Review is the highly cited journal. Out of top 10 cited papers nine are articles and six papers are single authored papers.

\section{REFERENCES}

1. Gupta, C. B. (2001). Modern business organization. New Delhi: Mayoor Paperbacks.

2. Zarah, L. (2018). 7 reasons why research is important. Retrieved on Dec 04, 2018, from https://owlcation.com/academia/Why-Research-isImportant-Within-and-Beyond-the-Academe

3. Bhardwaj, R. K. (2016). Scientometric analysis and dimensions on international business literature. Scientometrics, 106(1), 299-317. doi:10.1007/s11192-015-1777-1

4. Talukdar, D. (2011). Patterns of research productivity in the business ethics literature: Insights from analyses of bibliometric distributions. Journal of Business Ethics, 98(1), 137-151. doi:http://dx.doi.org/10.1007/s10551-010-0539-5

5. Dahlgaard-Park, S., \&Anninos, L. N. (2007). The archetype of excellence in universities and TQM. Journal of Management History, 13(4), 307-321. doi:10.1108/17511340710819561

6. Iritani, D. R., Morioka, S. N., De Carvalho, M. M., \&Ometto, A. R. (2015). Analysis of business process management theory and practices: Systematic literature review and bibliometrics. Gestao e Producao, 22(1), 164-180. doi:10.1590/0104-530X814-13

7. Sengar, P. P. S., Naqvi, S. A. R., \&Eqbal, M. (2012). Bibliometric analysis of pranjana: The journal of management awareness. Pranjana, 15(1), 63-70. Retrieved from https://search.proquest.com/docview/1430264297?accou ntid $=131615$

8. Calabretta, G., Durisin, B., \&Ogliengo, M. (2011) Uncovering the intellectual structure of research in business ethics: A journey through the history, the classics, and the pillars of journal of business ethics. Journal of Business Ethics, 104(4), 499-524. doi:http://dx.doi.org/10.1007/s10551-011-0924-8

9. Jabeen, M., Yun, L., Rafiq, M., \& Jabeen, M. (2015). Research productivity of library scholars. New Library World, 116(7), 433-454. Retrieved from https://search.proquest.com/docview/1688455356?accou ntid $=131615$

10. Fiala, D., \& Willett, P. (2015). Computer science in eastern europe 1989-2014: A bibliometric study. Aslib Journal of Information Management, 67(5), 526-541. Retrieved from https://search.proquest.com/docview/1712554412?accou ntid $=131615$

11. Pearson correlation coefficient calculator. Retrieved from https://www.socscistatistics.com/tests/pearson/

12. H-index. (2018).Retrieved https://en.wikipedia.org/wiki/H-index. 